\title{
SIGNIFICANCE OF CEPHALIN-CHOLESTEROL FLOCCULATION TEST IN MALARIAL FEVER ${ }^{1}$
}

\author{
By SAMUEL A. GUTTMAN, HARRY R. POTTER, FRANKLIN M. HANGER, \\ DAVID B. MOORE, PAUL S. PIERSON, AND DAN H. MOORE \\ (From the Neurological Institute of New York and the Departments of Neurology and \\ Medicine and the Electrophoresis Laboratory, College of Physicians and \\ Surgeons, Columbia University, New York City)
}

(Received for publication July 5, 1944)

The effect of malarial fever on hepatic physiology has recently been investigated. It has been found (1) that considerable bromsulphthalein retention, a marked reduction in cholesterol and cholesterol esters, a moderate fall in phospholipids, diminished hippuric acid excretion and a strongly positive cephalin-cholesterol flocculation reaction resulted when malaria was induced in 9 patients by inoculation with Plasmodium vivax for the treatment of central nervous system syphilis. Other investigators (2) studied 10 patients with acquired malaria in all of whom the cephalincholesterol reaction was positive. The aforementioned authors (3) noted a hypoproteinemia with a decrease in serum albumin and an increase in globulin in patients with therapeutic malarial fever. In this communication, data are presented dealing with changes in the various serum protein fractions occurring during malarial fever, and correlating these findings with the cephalincholesterol flocculation test.

\section{MATERIAL}

Six patients suffering from central nervous system syphilis were infected with Plasmodium vivax by the intravenous injection of malarial blood. Prior to the institution of malarial therapy each patient was subjected to a number of liver function tests and blood studies, which included determination of the prothrombin time (4), bromsulphthalein retention, using $5 \mathrm{mgm}$. of dye per $\mathrm{kgm}$. body weight with determinations 5 and 30 minutes after injection (5), alkaline phosphatase (6), serum bilirubin (7), serum cholesterol (8), cephalincholesterol flocculation (9), serum albumin and globulin by the salting-out method (10), occasional hippuric acid excretion tests; urine collected 1 hour after intravenous injection of 1.77 grams of sodium benzoate (11), nonprotein nitrogen (12), uric acid (13), and electrophoretic analysis of the blood serum (14). These and other studies were repeated at intervals during the

1 Aided in part by a grant from the William J. Matheson Commission. course of the malarial fever and also during the period of antimalarial therapy and convalescence. The patients in this group experienced from 74 to 134 hours of fever, $103^{\circ} \mathrm{F}$. or over.

\section{RESULTS}

All 6 patients developed a positive cephalincholesterol flocculation reaction during the course of malarial fever. In 4 patients, the test became positive after about 20 hours of fever, in 1 patient after 35 hours, and in the remaining patient after 70 hours. The test finally became 4 plus in 5 of 6 cases and 3 plus in the remaining case after 80 hours of fever. There was a marked reduction in serum cholesterol in all cases, some bromsulphthalein retention in 3 of the 6 , and an elevated serum bilirubin in 1 instance. Definite hypoproteinemia and hypoalbuminemia occurred in all cases. A slight increase in globulin was noted in 5 cases of the 6 (Table I), using the Howe method. No consistent significant changes were found in prothrombin time or in alkaline phosphatase values. Hippuric acid excretion studies were performed in only 2 cases and 1 showed no evidence of diminished excretion. Observations on a typical case are shown in Table II.

Electrophoretic analysis and separation of albumin and gamma globulin fraction were performed using the Tiselius method (14) with a number of sera as outlined in the preceding paper (15). Fractions were obtained from sera taken both before the institution of malarial therapy and before its termination. Electrophoretic separations were carried out in a buffer composed of $0.02 M$ sodium phosphate and $0.15 M$ sodium chloride at $\mathrm{pH} 7.4$ and the concentration of each fraction of albumin and gamma globulin obtained was determined by measuring its refractivity in a previously calibrated Zeiss interferometer (Figure 1). 
TABLE I

Showing the maximum change of some constituents of blood serum in patients with Plasmodium vivax infections

\begin{tabular}{|c|c|c|c|c|c|c|c|c|c|c|c|c|c|c|}
\hline \multirow{2}{*}{$\begin{array}{l}\text { Case } \\
\text { no. }\end{array}$} & \multirow{2}{*}{$\begin{array}{l}\text { No. of hours } \\
\text { with T. of } \\
103^{\circ} \text { or over }\end{array}$} & \multirow{2}{*}{$\begin{array}{c}\text { Weight } \\
\text { loss }\end{array}$} & \multicolumn{2}{|c|}{$\begin{array}{l}\text { Cephalin } \\
\text { flocculation }\end{array}$} & \multirow{2}{*}{$\underset{\text { bilirubin* }}{\text { Serum }}$} & \multicolumn{2}{|c|}{$\begin{array}{c}\text { Total } \\
\text { protein } \dagger\end{array}$} & \multicolumn{2}{|c|}{ Albumin $\dagger$} & \multicolumn{2}{|c|}{ Globulin $\dagger$} & \multicolumn{2}{|c|}{ Cholesterol } & \multirow{2}{*}{$\begin{array}{c}\text { Bromsulfph } \\
\text { thalein } \ddagger\end{array}$} \\
\hline & & & Before & $\begin{array}{l}\text { During } \\
\text { fever }\end{array}$ & & Before & $\begin{array}{l}\text { During } \\
\text { fever }\end{array}$ & Before & $\begin{array}{c}\text { During } \\
\text { fever }\end{array}$ & Before & $\begin{array}{c}\text { During } \\
\text { fever }\end{array}$ & Before & $\begin{array}{c}\text { During } \\
\text { fever }\end{array}$ & \\
\hline $\begin{array}{l}1 \\
2 \\
3 \\
4 \\
5 \\
6\end{array}$ & $\begin{array}{r}74 \\
88 \\
79 \\
134 \\
87 \\
80\end{array}$ & $\begin{array}{l}l b s . \\
8 \\
6 \\
4 \frac{1}{2} \\
? \\
7 \\
6\end{array}$ & $\begin{array}{l}0 \\
0 \\
0 \\
0 \\
0 \\
0\end{array}$ & $\begin{array}{l}4+ \\
4+ \\
4+ \\
4+ \\
4+ \\
3+\end{array}$ & $\begin{array}{c}\text { mgm. per cent } \\
0.9 \\
1.8 \\
0.5 \\
0.5 \\
0.5 \\
0.5\end{array}$ & $\begin{array}{l}7.0 \\
7.5 \\
7.1 \\
6.4 \\
7.5 \\
6.2\end{array}$ & \begin{tabular}{l|}
\multicolumn{2}{c}{ gram } \\
5.7 \\
5.2 \\
5.8 \\
5.8 \\
6.7 \\
5.8
\end{tabular} & $\begin{array}{l}\text { ms per } 10 \\
\begin{array}{|c|}5.0 \\
5.0 \\
5.1 \\
4.3 \\
5.2 \\
4.3\end{array}\end{array}$ & \begin{tabular}{|c|}
$0 \mathrm{ml} . \mathrm{ser}$ \\
3.3 \\
2.9 \\
3.2 \\
2.9 \\
3.9 \\
3.6
\end{tabular} & $\begin{array}{r}u m \\
2.0 \\
2.5 \\
2.0 \\
2.1 \\
2.3 \\
1.9\end{array}$ & $\begin{array}{l}2.4 \\
2.3 \\
2.6 \\
2.9 \\
2.8 \\
2.2\end{array}$ & $\begin{array}{l}m g m . \\
205 \\
292 \\
196 \\
231 \\
242 \\
322\end{array}$ & \begin{tabular}{|} 
per cent \\
65 \\
114 \\
92 \\
82 \\
133 \\
149
\end{tabular} & $\begin{array}{l}\text { per cent } \\
80 / 18 \\
95 / 35 \\
75 / 5 \\
55 / 5 \\
80 / 0 \\
70 / 10\end{array}$ \\
\hline
\end{tabular}

* Highest value.

$\dagger$ By the salting-out method of Howe.

$\ddagger$ Maximum retention using $5 \mathrm{mgm}$. of dye per $\mathrm{kgm}$. body weight, with specimens taken at 5 and 30 minute intervals.

Because of the findings of others. (16) confirmed by the preceding paper (15) that, in acute hepatitis, a rise in gamma globulin is only demonstrable by use of the Tiselius method, comparison of the protein changes were made using both the Howe salting-out and the electrophoretic procedures. These changes in albumin and globulin by the two methods before and during malaria are recorded in Table III and show that malarial fever induces hypoproteinemia and hypoalbuminemia. There is but slight increase in globulin by the salting-out method, whereas by electrophoresis there is considerable increase in globulin, particularly in the gamma fraction.

The electrophoretically separated albumin was studied, by the methods previously outlined (15),

TABLE II

Changes in some constituents of blood serum in a patient with Plasmodium vivax infection

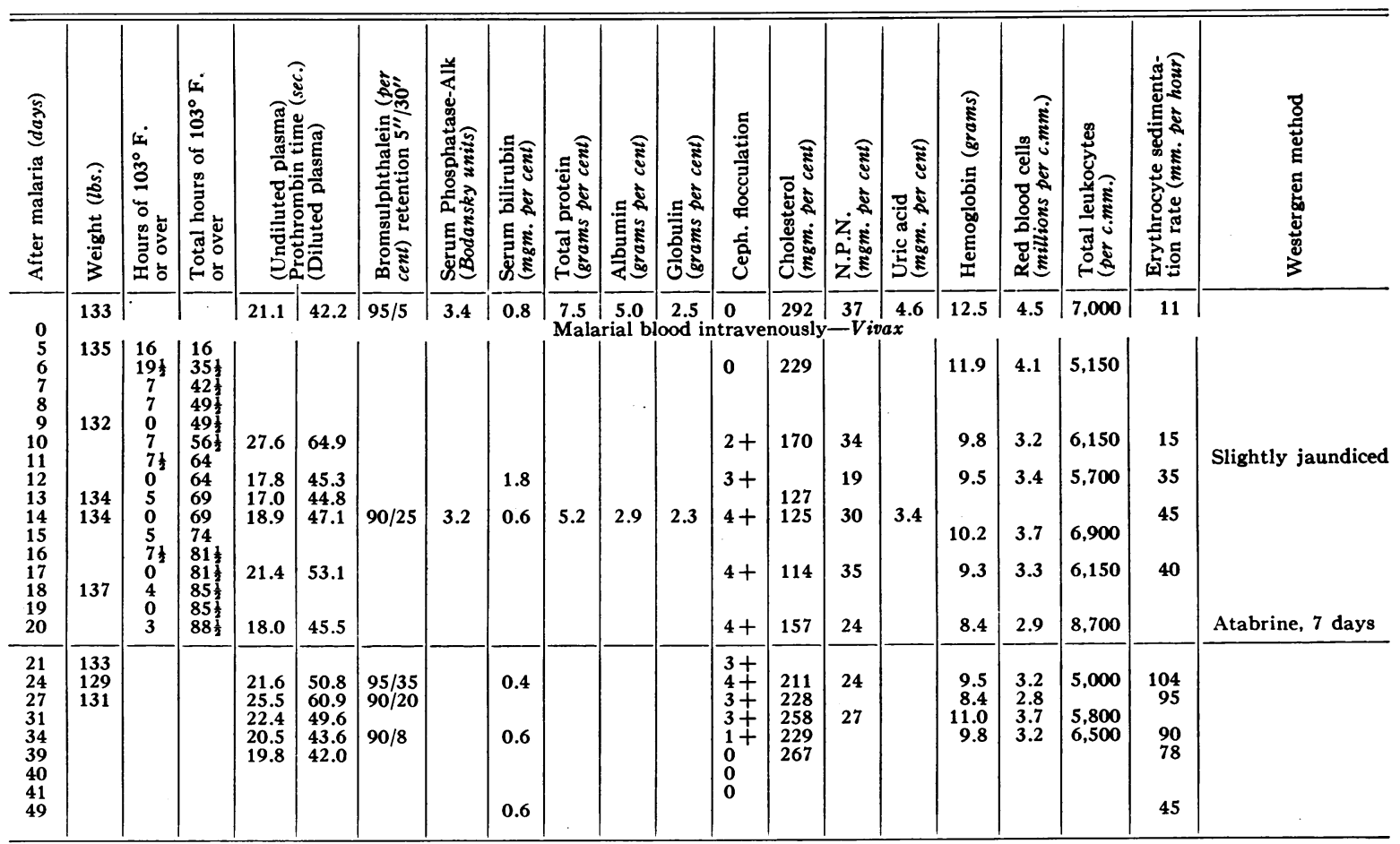




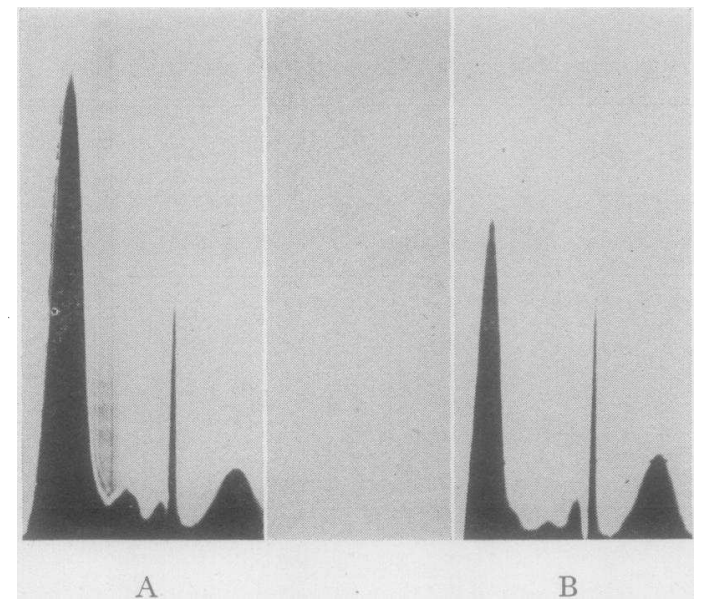

Fig. 1. Electrophoresis Patterns of Serum Taken from Patient No. 1

A. Before therapeutic malaria. B. During active malaria. Descending patterns. Buffer, $0.02 M$ sodium phosphate and $0.15 \mathrm{M} \mathrm{NaCl}, \mathrm{pH} 7.4$.

to determine if the changes noted in hepatitis were also present in patients with malarial fever.

Three series of 5 tubes which contained diminishing amounts of isolated gamma globulin, from $0.60 \mathrm{mgm}$. to $0.12 \mathrm{mgm}$. were prepared. In this range, the gamma globulin fraction alone gives a cephalin-cholesterol flocculation range from 4 plus to negative (17). The effect of the addition of serum albumin obtained from blood, taken both before the institution of the malarial therapy and before its termination, was determined. Striking inhibition of flocculation occurred in all of the series of tubes containing $5 \mathrm{mgm}$. of albumin from blood taken before the institution of malarial infection. In the series of tubes, however, containing $5 \mathrm{mgm}$. of the albumin fraction from the serum of patients obtained during active malarial infection, there was but slight inhibition of flocculation in one instance (Case 1) and no inhibition in the other (Case 2) (Table IV). In the one instance tested, no differences were observed in the reaction when the gamma globulin obtained during malaria was substituted for pre-malarial gamma globulin.

\section{DISCUSSION}

The 6 patients studied were suffering from central nervous system syphilis and therefore may have had changes in their serum protein patterns some time previously. The possibility of tertiary syphilis or of anti-luetic therapy affecting the serum protein response in malaria cannot be excluded. However, all tests before the malarial induction were within normal limits, except the serological tests for syphilis.

The most consistent changes incident to the malaria shown by these studies were: (1) Decrease in serum cholesterol; (2) the development of a strongly positive cephalin-cholesterol flocculation test $(1,2)$; and (3) a marked hypoproteinemia, hypoalbuminemia, and an increase in globulin, especially gamma globulin. These find-

TABLE III

Electrophoretic and salt fractionation (Howe method) of blood serum before and during active Plasmodiun vivax infection

\begin{tabular}{|c|c|c|c|c|c|c|c|c|c|c|c|c|}
\hline \multirow{3}{*}{ Patient } & \multirow{3}{*}{$\frac{\text { Before }}{\text { During }}$} & \multicolumn{7}{|c|}{ Electrophoretic fractionation* } & \multicolumn{4}{|c|}{ Salt fractionation-per cent } \\
\hline & & \multirow{2}{*}{$\begin{array}{l}\text { Total } \\
\text { protein }\end{array}$} & \multicolumn{5}{|c|}{ Globulin } & \multirow{2}{*}{$\frac{\text { Albumin }}{\text { Globulin }}$} & \multirow{2}{*}{$\begin{array}{l}\text { Total } \\
\text { protein }\end{array}$} & \multirow{2}{*}{ Albumin } & \multirow{2}{*}{ Globulin } & \multirow{2}{*}{$\mathrm{A} / \mathrm{G}$} \\
\hline & & & Albumin & $\alpha$ & $\beta$ & $\gamma$ & Total & & & & & \\
\hline \multirow{2}{*}{ Case I } & B & 7.2 & 5.1 & 0.43 & 0.75 & 1.00 & 2.18 & 2.4 & 7.0 & 5.0 & 2.0 & 2.5 \\
\hline & $\overline{\mathrm{D}}$ & 6.3 & 3.3 & 0.30 & 1.03 & 1.63 & 2.96 & 1.1 & 5.7 & 3.3 & 2.4 & 1.4 \\
\hline \multirow{2}{*}{ Case II } & B & 6.8 & 4.3 & 0.40 & 1.00 & 1.10 & 2.50 & 1.7 & 7.5 & 5.0 & 2.5 & 2.0 \\
\hline & $\overline{\mathrm{D}}$ & 5.7 & 2.9 & 0.32 & 1.03 & 1.67 & 3.02 & 1.0 & 5.2 & 2.9 & 2.3 & 1.3 \\
\hline \multirow{2}{*}{ Case III } & B & 6.8 & 4.5 & 0.47 & 0.83 & 0.87 & 2.17 & 2.0 & 7.1 & 5.1 & 2.0 & 2.5 \\
\hline & $\overline{\mathrm{D}}$ & 5.8 & 3.3 & 0.37 & 1.06 & 1.06 & 2.59 & 1.3 & 5.8 & 3.2 & 2.6 & 1.2 \\
\hline
\end{tabular}

* Deduced from pattern areas assuming the same specific refractivity for all components. This introduces some error since it is known that the specific refractivity of the components vary among themselves. 
TABLE IV

The effect of albumin on the cephalin-cholesterol flocculating power of gamma globulin: a. before Plasmodium vivax infection

b. during active infection

\begin{tabular}{|c|c|c|c|c|c|}
\hline & \multicolumn{5}{|c|}{ Gamma globulin in diminishing amounts } \\
\hline & $0.6 \mathrm{mgm}$. & $0.48 \mathrm{mgm}$. & $0.36 \mathrm{mgm}$. & $0.24 \mathrm{mgm}$. & $0.12 \mathrm{mgm}$. \\
\hline $\begin{array}{l}\text { Pre-malarial isolated gamma globulin fraction from Case I } \\
\text { Pre-malarial isolated gamma globulin fraction from Case I, } \\
\text { plus } 5 \mathrm{mgm} \text {. pre-malarial albumin fraction from Case I } \\
\text { Pre-malarial isolated gamma globulin fraction from Case I, } \\
\text { plus } 5 \mathrm{mgm} \text {. post-malarial albumin fraction from Case I }\end{array}$ & $\begin{array}{l}+++ \\
++ \\
++t\end{array}$ & $\begin{array}{l}++t \\
\quad \pm \\
++t\end{array}$ & $\begin{array}{l}+++ \\
0 \\
++\end{array}$ & $\begin{array}{l}++ \\
0 \\
\pm\end{array}$ & $\begin{array}{l} \pm \\
0 \\
0\end{array}$ \\
\hline $\begin{array}{l}\text { Pre-malarial isolated gamma globulin fraction from Case II } \\
\text { Pre-malarial isolated gamma globulin fraction from Case II, } \\
\text { plus } 5 \mathrm{mgm} \text {. pre-malarial albumin fraction from Case II } \\
\text { Pre-malarial isolated gamma globulin fraction from Case II, } \\
\text { plus } 5 \mathrm{mgm} \text {. post-malarial albumin fraction from Case II }\end{array}$ & $\begin{array}{c}++t+ \\
0 \\
+++t\end{array}$ & $\begin{array}{c}+++ \\
0 \\
+++\end{array}$ & $\begin{array}{c}+t \\
0 \\
++\end{array}$ & $\begin{array}{l} \pm \\
0 \\
\pm\end{array}$ & $\begin{array}{l}0 \\
0 \\
0\end{array}$ \\
\hline
\end{tabular}

ings, if indicative of a disorder in the liver, contrast sharply with the results of other hepatic function tests such as bromsulphthalein excretion, hippuric acid synthesis, prothrombin time, and serum phosphatase values, which are often unchanged during malarial infection.

A weakly positive cephalin-cholesterol flocculation test appears early in the infection and gradually becomes strongly positive. In malaria, all three changes in the serum proteins which theoretically could produce a positive reaction (15) may account for the positive cephalin-cholesterol flocculation reaction. The marked diminution of serum albumin and the decreased inhibiting power of the electrophoretically separated albumin fraction suggest that the mechanism for synthesis of the components of the normal albumin fraction is conspicuously impaired during malarial infection. This derangement is similar to that observed in hepatitis. In the case of malaria, however, the change is more marked than other disturbances of the liver as manifested by the conventional liver function tests.

\section{SUM MARY}

1. The cephalin-cholesterol flocculation test becomes strongly positive in therapeutic malarial fever.

2. This is associated with a definite hypoproteinemia, hypoalbuminemia, and some increase in total globulin and especially in gamma globulin.

3. The serum albumin fraction during active infection shows a greatly decreased capacity to inhibit the cephalin-cholesterol flocculating properties of gamma globulin.

4. The positive cephalin-cholesterol flocculation reaction in malaria is probably due to: (1) hypoalbuminemia, (2) a decreased capacity of the serum albumin fraction to inhibit the flocculating action of gamma globulin, and (3) an increase in the gamma globulin content of the serum in this disease.

5. These changes resemble those seen in acute hepatitis.

6. In malarial infection, the formation of serum protein is more profoundly deranged than many other functions ascribed to the liver and these changes are well demonstrated by a series of cephalin-cholesterol flocculation tests.

\section{BIBLIOGRAPHY}

1. Kopp, I., and Solomon, H. C., Liver function in therapeutic malaria. Am. J. M. Sc., 1943, 205, 90.

2. Mirsky, I. A., von Brecht, R., and Williams, L. D., Hepatic dysfunction in malaria. Science, 1944, 99, 20.

3. Kopp, I., and Solomon, H. C., The relationship of hypoalbuminemia to the edema of malaria. Am. J. M. Sc., 1941, 202, 861.

4. Shapiro, S., Sherwin, B., Redish, M., and Campbell, H. A., Prothrombin estimation: a procedure and clinical interpretations. Proc. Soc. Exper. Biol. and Med., 1942, 50, 85.

5. Rosenthal, S. M., and White, E. C., Clinical application of the bromsulphalein test for hepatic function. J. A. M. A., 1925, 84, 1112.

6. Bodansky, A., Notes on the determination of serum inorganic phosphate and serum phosphatase activity. J. Biol. Chem., 1937, 120, 167. 
7. Thannhauser, S. J., and Anderson, E., Methodik der quantitativen Bilirubinbestimmung in menschlichen Serum. Deutsches Arch. f. klin. Med., 1921, 137, 179.

8. Bloor, W. R., and Knudson, A., The separate determination of cholesterol and cholesterol esters in small amounts of blood. J. Biol. Chem., 1916, 27, 107.

9. Hanger, F. M., The flocculation of cephalincholesterol emulsions by pathological sera. Tr. A. Am. Physicians, 1938, 53, 148.

10. Howe, P. E., The determination of proteins in blood-a micro method. J. Biol. Chem., 1921, 49, 109.

11. Quick, A. J., Intravenous modification of the hippuric acid test for liver function. Am. J. Digest. Dis., 1939, 6, 716.

12. Todd, J. C., and Sanford, A. H., Clinical Diagnosis by Laboratory Methods. W. B. Saunders and
Co., Philadelphia and London, 1940, 9th Edition, p. 350 .

13. Folin, O., Laboratory Manual of Biological Chemistry. D. Appleton-Century Co., Inc., New York and London, 1934, 5th Edition, p. 297.

14. Tiselius, A., A new apparatus for electrophoretic analysis of colloidal mixtures. Trans. Faraday Soc., 1937, 33, 524.

15. Moore, D. B., Pierson, P. S., Hanger, F. M., and Moore, D. H., Mechanism of the positive cephalincholesterol flocculation reaction in hepatitis. J. Clin. Invest., 1945, 24, 292.

16. Gray, S. J., and Barron, E. S. G., The electrophoretic analyses of serum proteins in diseases of the liver. J. Clin. Invest., 1943, 22, 191.

17. Kabat, E. A., Hanger, F. M., Moore, D. H., and Landow, $H$., The relation of cephalin flocculation and colloidal gold reactions to the serum proteins. J. Clin. Invest., 1943, 22, 563. 